\title{
Komposisi Vegetasi Mangrove di Muara Sungai Siganoi Sorong Selatan - Papua
}

\author{
Mangrove Vegetation Composition in Delta Siganoi River, South Sorong, Papua
}

\author{
Yohanes Y. Rahawarin
}

Pusat Penelitian Keanekaragaman Hayati Universitas Negeri Papua Manokwari

Jl. Gunung Salju Amban Manokwari (98314)

Email : yohanesrahawarin@yahoo.com

\begin{abstract}
The research was aimed to figure out the structure and composition of mangrove species in the delta of Siganoi River, Inanwatan District, South Sorong Regency, Papua. Belt transect was used and the data was analyzed using formula according to Clintron and Novelly. Research showed that ten species (seven genus) from five families were found in this area. At tree and sapling stages, Sonneratia alba performed the highest density with 324,1 trees/ha and 765,5 sapling/ha respectively, while at seedling stage Aegiceras corniculatumc with 69 seedling/ha. The highest frequency was found on trees and sapling of Sonneratia alba 0,966 and 0,431 respectevely. At the seedling stage, the highest frequency was found on species Aegiceras corniculatum (3970).
\end{abstract}

Key words : vegetation composition, mangrove forest, Siganoi river, South Sorong, Papua

Diterima : 26 Juni 2004, disetujui : 08 Maret 2005

\section{Pendahuluan}

Wilayah laut yang produktif adalah wilayah laut yang dangkal tempat sejumlah komunitas bahari yang produktif seperti mangrove, padang lamun dan terumbu karang hidup. Indonesia memiliki garis pantai kurang lebih $81.000 \mathrm{~km}$ dengan komunitas mangrove yang tumbuh hampir di sepanjang garis pantai.

Hutan mangrove menggambarkan suatu varietas komunitas pantai tropis yang didominasi oleh pohon-pohon yang khas atau semak-semak yang mempunyai kemampuan untuk tumbuh pada perairan asin. Hutan mangrove mendominasi kira-kira seperempat garis pantai daerah tropis. Di Indonesia hutan mangrove tersebar hampir di seluruh pantai pulau-pulau besar mulai dari Sumatera sampai Papua. Mangrove tumbuh pada pantai yang terlindung umumnya pada daerah-daerah teluk dengan gerakan ombak yang minim.
Mangrove tidak tumbuh pada pantai yang terjal dan bergelombang besar dengan arus pasang surut yang kuat, karena hal ini tidak memungkinkan terjadinya pengendapan lumpur dan pasir, sebagai substrat yang diperlukan untuk pertumbuhannya (Dahuri et al., 1996). Ekosistem mangrove merupakan ekosistem yang kompleks dan khas serta memiliki daya dukung yang besar terhadap lingkungan perairan yang ada di sekitarnya.

Disamping dapat digunakan sebagai benteng pantai terhadap hempasan ombak, hutan mangrove juga bisa dipandang sebagai penghasil unsur hara yang berasal dari serasah. Unsur hara ini berperan penting untuk menentukan besarnya kandungan produktifitas suatu perairan. Selain itu mangrove berfungsi sebagai tempat memijah, bertelur, asuhan, tempat makan dan pembesaran bagi berbagai jenis anak ikan dan udang (Bengen, 2002). Darsidi (1986) menyatakan bahwa potensi dari hutan mangrove dapat ditinjau dari dua aspek 
yaitu potensi ekologis dan potensi ekonomis. Potensi ekologis lebih ditekankan pada kemampuannya dalam mendukung eksistensi lingkungan sebagai penahan angin, penahan gempuran ombak, pengendali banjir dan sebagai tempat persembunyian, mencari makan, serta tempat pemeliharaan berbagai macam hewan air. Sedangkan potensi ekonomis dapat berupa kayu bakar, kosmetika, obat-obatan, bahan bangunan dan lain-lain (Dahuri et al., 1996).

Pentingnya peranan hutan mangrove terhadap perairan di sekitarnya maka pengetahuan mengenai kondisi ekosistim hutan mangrove di suatu perairan pantai akan sangat bermanfaat terutama di tempat yang belum pernah dilakukan penelitian sebelumnya. Penelitian ini bertujuan untuk mengetahui komposisi dan struktur jenis mangrove di perairan muara sungai Siganoi distrik Inanwatan kabupaten Sorong Selatan, Papua. Manfaat yang dapat diperoleh dari penelitian ini adalah menyediakan data dasar sebagai bahan informasi untuk keperluan monitoring kondisi ekosistem mangrove.

\begin{tabular}{|c|c|c|}
\hline \multirow{2}{*}{ 1. Kerapatan Jenis $(\mathrm{KJ})=$} & Jumlah individu suatu jenis & \multirow{4}{*}{$\times 100 \%$} \\
\hline & Luas daerah pengamatan & \\
\hline \multirow{2}{*}{ Kerapatan Relatif $(\mathrm{KR})=$} & Jumlah individu suatu jenis & \\
\hline & Jumlah total individu semua jenis & \\
\hline \multirow{2}{*}{ 2. Frekuensi Jenis $(\mathrm{FJ})=$} & Jumlah kuadran terdapatnya jenis & \\
\hline & Jumlah total kuadran/kuadrat plot & yg diteliti \\
\hline \multirow{2}{*}{ Frekwensi Relatif $(\mathrm{FR})=$} & Frekwensi suatu spesies & \multirow{2}{*}{$\times 100 \%$} \\
\hline & Jumlah frekwensi seluruh spesies & \\
\hline \multirow{2}{*}{ 3. Dominansi Jenis $(\mathrm{DJ})=$} & Jumlah basal area suatu jenis & \\
\hline & Luas daerah pengamatan & \\
\hline \multirow[b]{2}{*}{ Dominansi Relatif $(\mathrm{DR})=$} & Jumlah dominansi suatu jenis & \multirow[b]{2}{*}{$100 \%$} \\
\hline & $\overline{\text { Jumlah dominansi Semua Jenis }}$ & \\
\hline
\end{tabular}

4. Nilai Penting $(\mathrm{NP})=$ Kerapatan Relatif + Frekuensi Relatif + Dominansi Relatif

Biota Vol. X (3), Oktober 2005 


\section{Hasil dan Pembahasan}

\section{Komposisi Spesies}

Hasil inventarisasi vegetasi mangrove di pesisir muara sungai Siganoi dengan menggunakan metode belt transek diperoleh 58 petak pengamatan yang terbagi dalam 17 transek, ditemukan tujuh famili yang meliputi 12 spesies mangrove, seperti pada Tabel 1.

Tabel 1. Komposisi Spesies Mangrove di Pesisir Muara Sungai Siganoi

\begin{tabular}{cll}
\hline \hline No & Famili & Spesies \\
\hline \hline 1. & Rhizophoraceae & Rhizophora apiculata \\
& & Rhizophora stylosa \\
& & Rhizophora mucronata \\
& & Bruguiera gymnorrhiza \\
& & Ceriops tagal \\
2. & Sonneratiaceae & Sonneratia alba \\
3. & Avicenniaceae & Avicennia alba \\
& & Avicennia marina \\
4. & Myrsinaceae & Aegiceras corniculatum \\
5. & Meliaceae & Xylocarpus granatum \\
6. & Acanthaceae & Acanthus ilicifolius \\
7. & Arecaceae & Nypa fructicans \\
\hline \hline
\end{tabular}

Dilihat dari jumlah spesies yang ditemukan, maka famili Sonneratiaceae memiliki jumlah spesies terbanyak dibanding dengan famili lainnya. Komposisi spesies di muara sungai Siganoi menunjukkan tidak terdapat perbedaan jumlah jenis yang sangat mencolok, bila dibandingkan dengan hasil penelitian Onrizal (1997) di areal hutan mangrove teluk Bintuni, Papua yang menemukan 13 spesies dari enam famili vegetasi mangrove.

\section{Struktur Komunitas Mangrove}

\section{Kerapatan Spesies}

Nilai kerapatan spesies dan kerapatan relatif vegetasi mangrove pada pesisir muara sungai Siganoi disajikan pada Tabel 2.

Tabel 2. Hasil Perhitungan Nilai Kerapatan dan Kerapatan Relatif Spesies Mangrove

\begin{tabular}{clrrrrrr}
\hline \multirow{2}{*}{ No } & \multirow{2}{*}{ Spesies Mangrove } & \multicolumn{2}{c}{ Kerapatan Spesies (ind/Ha) } & \multicolumn{3}{c}{ Kerapatan Relatif (\%) } \\
\cline { 3 - 7 } & & Pohon & Sapihan & Anakan & Pohon & Sapihan & Anakan \\
\hline \hline 1 & Sonneratia alba & 324,1 & 765,5 & 26720 & 67,17 & 51,86 & 26,49 \\
2 & A. corniculatum & 69,0 & 531,2 & 69660 & 14,29 & 35,99 & 69,07 \\
3 & Rh. Mucronata & 10,3 & 27,6 & 170 & 2,13 & 1,87 & 0,17 \\
4 & Rh. Apiculata & 6,9 & 27,6 & 520 & 1,43 & 1,87 & 0,52 \\
5 & Rh. Stylosa & 22,4 & 55,2 & 1030 & 4,64 & 3,74 & 1,02 \\
6 & Avicenia marina & 17,2 & 6,8 & 2590 & 3,56 & 0,46 & 2,56 \\
7 & Avicenia alba & 8,6 & 20,8 & 170 & 1,78 & 1,41 & 0,17 \\
8 & X. granatum & 1,7 & 0 & 0 & 0,36 & 0 & 0 \\
9 & Br.gymnorrhiza & 8,6 & 6,8 & 0 & 1,78 & 0,46 & 0 \\
10 & Ceriops tagal & 13,8 & 34,4 & 0 & 2,86 & 2,34 & 0 \\
\hline \hline & Jumlah & 482,6 & 1475,9 & 100860 & 100 & 100 & 100 \\
\hline \hline
\end{tabular}

Berdasarkan Tabel 2 diketahui bahwa Sonneratia alba dan A. corniculatum memiliki kerapatan spesies tertinggi untuk semua tingkat 136 pertumbuhan. Sonneratia alba memiliki kerapatan spesies terbesar untuk pada tingkat pohon sebesar 324,1 ind/ha $(67,17 \%)$, diikuti Biota Vol. X (3), Oktober 2005 
oleh $A$. corniculatum dengan kerapatan spesies sebesar 69 ind/ha $(14,29 \%)$. Untuk tingkat pertumbuhan sapihan kerapatan spesies tertinggi adalah spesies $S$. alba dengan nilai $765,5 \mathrm{ind} / \mathrm{ha}(51,86 \%)$, selanjutnya diikuti oleh A. corniculatum dengan kerapatan spesiesnya sebesar 531,2 ind/ha (35,99\%). Sedangkan untuk tingkat anakan spesies $A$. corniculatum memiliki nilai kerapatan spesies tertinggi sebesar 69660 ind/ha $(69,07 \%)$, diikuti oleh spesies S. alba dengan nilai kerapatan spesies dan kerapatan relatifnya sebesar $26720 \mathrm{ind} /$ ha $(26,49 \%)$.

Tingginya nilai kerapatan spesies yang didominasi oleh spesies $S$. alba untuk kategori pohon dan sapihan dan A. corniculatum untuk anakan pada lokasi mura sungai Siganoi ini akibat kondisi substrat yang sangat cocok bagi perkembangan spesies ini. Kemampuan kedua spesies ini untuk beradaptasi terhadap keadaan pesisir muara sungai Siganoi yang berhubungan langsung dengan laut bebas sehingga memungkinkan sering terjadi gelombang laut yang cukup kuat.

\section{Frekuensi Spesies}

Doubenmire (1974) menyatakan bahwa salah satu faktor yang membatasi penyebaran suatu jenis tumbuhan adalah persaingan antar jenis baik persaingan untuk mendapatkan air, unsur hara, maupun sinar matahari. Persaingan untuk mendapatkan unsur hara ditentukan oleh jumlah nitrogen yang diserap dan penyebaran sistem perakaran. Penyerapan unsur hara tergantung pada keadaan tanah dan daya serap akar tanaman. Persaingan mendapatkan sinar matahari tergantung pada kecepatan pertumbuhan pada stadium permulaan dari tanaman, serta bentuk tumbuhan. Jenis tumbuhan yang menang dalam pertumbuhan ini akan tersebar lebih luas dan jumlah individu per satuan luas akan lebih besar. Berdasarkan pendapat Doubenmire (1974) dapat dikatakan bahwa tumbuhan yang mempunyai daerah penyebaran luas (frekuensi spesies/frekuensi relatif besar) juga mempunyai kecenderungan jumlah individu per satuan luasnya besar (kerapatan spesies/kerapatan relatif).

Hasil perhitungan frekuensi spesies dan frekuensi relatif mangrove di pesisir muara sungai Siganoi distrik Inanwatan dapat dilihat pada Tabel 3.

Tabel 3. Hasil Perhitungan Nilai Frekuensi dan Frekuensi Relatif Spesies Mangrove

\begin{tabular}{clrrrrrr}
\hline \hline \multirow{2}{*}{ No } & \multirow{2}{*}{ Spesies Mangrove } & \multicolumn{3}{c}{ Frekuensi Spesies } & \multicolumn{3}{c}{ Frekuensi Relatif (\%) } \\
\cline { 3 - 7 } & & Pohon & Sapihan & Anakan & Pohon & Sapihan & Anakan \\
\hline \hline 1 & Sonneratia alba & 0.966 & 0.431 & 0.310 & 61.61 & 44.71 & 35.31 \\
2 & A. corniculatum & 0.172 & 0.241 & 0.397 & 10.97 & 25.00 & 45.22 \\
3 & Rh. Mucronata & 0.052 & 0.017 & 0.034 & 3.32 & 1.76 & 3.87 \\
4 & Rh. Apiculata & 0.069 & 0.069 & 0.034 & 4.40 & 7.16 & 3.87 \\
5 & Rh. Stylosa & 0.086 & 0.103 & 0.052 & 5.48 & 10.68 & 5.92 \\
6 & Avicenia marina & 0.103 & 0.034 & 0.034 & 6.57 & 3.53 & 3.87 \\
7 & Avicenia alba & 0.052 & 0.017 & 0.017 & 3.32 & 1.76 & 1.94 \\
8 & X. granatum & 0.017 & 0.000 & 0.000 & 1.08 & 0.00 & 0.00 \\
9 & Br.gymnorrhiza & 0.017 & 0.052 & 0.000 & 1.08 & 5.39 & 0.00 \\
10 & Ceriops tagal & 0.034 & 0.000 & 0.000 & 2.17 & 0.00 & 0.00 \\
\hline \hline
\end{tabular}

Berdasarkan nilai frekuensi spesies dan frekuensi relatif pada Tabel 3 didapatkan bahwa pada tingkat pertumbuhan pohon, sapihan dan anakan spesies yang mempunyai daerah penyebaran paling luas adalah Sonneratia Alba dan A. Corniculatum. Pada tingkat pertumbuhan pohon dan sapihan
S. alba memiliki nilai frekuensi spesies terbesar yaitu $0,966(61,61 \%)$ dan 0,431 $(44,71 \%)$. Selanjutnya diikuti oleh spesies $A$. corniculatum dengan nilai $0,172(10,97 \%)$ untuk tingkat pohon dan 0,241 $(25,00 \%)$ untuk tingkat sapihan. Pada tingkat pertumbuhan anakan nilai frekuensi spesies tertinggi 
ditunjukkan oleh spesies $A$. corniculatum dengan nilai 0,397 (45,22\%), kemudian diikuti oleh spesies $S$. alba dengan nilai frekuensi spesies sebesar 0,310 (35,31\%).

Nilai frekuensi spesies dan frekuensi relatif yang tinggi dari jenis-jenis $S$. alba dan A. corniculatum menunjukkan kemampuan adaptasi yang besar terhadap lingkungan di muara sungai Siganoi, sehingga mempunyai daerah penyebaran yang luas. Keadaan substrat yang sebagian besar berupa pasir bercampur lumpur memungkinkan untuk spesies-spesies tersebut tumbuh dan berkembang dengan baik serta dijumpai hampir pada semua kuadran pengamatan tersebut. Keadaan ini sesuai dengan yang dilaporkan Setyawan et al., (2005) yang mengatakan bahwa sebararan spesies tumbuhan mangrove juga terkait dengan kemampuan beradaptasi terhadap kondisi lingkungan. Tumbuhan mangrove umumnya memiliki bentuk morfologi dan mekanisme fisiologi tertentu untuk beradaptasi terhadap garam, adaptasi sistem reproduksi (propagul), dan adaptasi terhadap tanah yang gembur dan bersifat anoksik (anaerob).

\section{Dominasi Spesies}

Dominasi menunjukkan penguasaan suatu jenis terhadap jenis yang lain dalam tegakan, yang dinyatakan berdasarkan besaran luas bidang dasar setinggi dada. Nilai dominasi spesies secara keseluruhan pada pesisir muara sungai Siganoi disajikan pada Tabel 4.

Tabel 4. Hasil Perhitungan Nilai Dominasi dan Dominasi Relatif Spesies Mangrove

\begin{tabular}{clrrrr}
\hline \hline \multirow{2}{*}{ No } & \multirow{2}{*}{ Spesies Mangrove } & \multicolumn{2}{c}{ Dominasi Spesies } & \multicolumn{2}{c}{ Dominasi Relatif (\%) } \\
\cline { 3 - 5 } & & Pohon & Sapihan & Pohon & Sapihan \\
\hline \hline 1 & Sonneratia alba & 236990,56 & 23338,46 & 83,74 & 53,29 \\
2 & Aegiceras corniculatum & 13746,29 & 15565,01 & 4,86 & 35,54 \\
3 & Rhizophora mucronata & 3079,15 & 92,80 & 1.09 & 0,20 \\
4 & Rhizophora apiculata & 2257,58 & 561,17 & 0,80 & 1,28 \\
5 & Rhizophora stylosa & 5295,82 & 1925,10 & 1,87 & 4,39 \\
6 & Avicenia marina & 4665,06 & 177,90 & 1,65 & 0,42 \\
7 & Avicenia alba & 3605,04 & 685,81 & 1,27 & 1,57 \\
8 & X. granatum & 6643,97 & 0 & 2,35 & 0 \\
9 & Brugueira gymnorrhiza & 4369,92 & 0 & 1,54 & 0 \\
10 & Ceriops tagal & 2351,61 & 1448,50 & 0,83 & 3,31 \\
\hline \hline & Jumlah & 283005 & 43794,75 & 100 & 100 \\
\hline \hline
\end{tabular}

Tabel 4 menunjukkan nilai dominasi spesies $S$. alba yang terbesar pada tingkat pertumbuhan pohon dan sapihan di muara sungai Siganoi. Nilai dominasi spesies $S$. alba yaitu sebesar $236990 \mathrm{ind} / \mathrm{ha}(83,74 \%)$, diikuti oleh dominasi spesies dari A. corniculatum sebesar 13746,29 ind/ha $(4,86 \%)$. Untuk tingkat pertumbuhan sapihan masih didominasi oleh spesies $S$. alba dengan nilai dominasi spesies tertinggi sebesar 23338,46 ind/ha (53,29\%), kemudian diikuti oleh spesies $A$. corniculatum dengan nilai dominasi spesies dan dominasi relatifnya sebesar 15565,01 ind/ha $(35,54 \%)$.

Kawasan hutan mangrove di muara sungai Siganoi yang langsung berhubungan dengan laut bebas memungkinkan terjadinya gelombang laut yang cukup kuat sehingga spesies-spesies tertentu saja yang dapat bertahan hidup. Di samping itu lokasi ini mudah dijangkau oleh penduduk, sehingga mendapat tekanan yang kuat berupa pemenuhan kebutuhan masyarakat dengan cara penebangan untuk pemanfaatan kayu bakar, kayu bangunan yang sangat mengancam kelestarian hidupnya. Setyawan et al., (2005) mengatakan bahwa secara kultural, kehidupan masyarakat dapat mempengaruhi keberadaan tumbuhan mangrove di suatu lokasi.

\section{Nilai Penting}

Nilai penting suatu jenis akan mencapai nilai maksimum sebesar 300 jika dalam komunitas tersebut hanya terdapat suatu jenis saja (Mueller-Dombois dan Ellenberg, 1974). 
Suatu jenis yang mempunyai nilai penting yang besar, maka akan semakin besar pula peranan jenis tersebut dalam suatu komunitas. Nilai penting untuk kategori Pohon dan Sapihan dapat dilihat pada Tabel 5 dan Tabel 6.

Tabel 5. Hasil Perhitungan Nilai Penting Untuk Kategori Pohon

\begin{tabular}{clrrrrrrr}
\hline \hline No & Spesies Mangrove & \multicolumn{1}{c}{ KJ } & KR & \multicolumn{1}{c}{ FJ } & \multicolumn{1}{c}{ FR } & \multicolumn{1}{c}{ DJ } & \multicolumn{1}{c}{ DR } & \multicolumn{1}{c}{ NP } \\
\hline \hline 1 & Sonneratia alba & 324,1 & 67,17 & 96,6 & 61,61 & 236990,56 & 83,74 & 212,52 \\
2 & A. corniculatum & 69,0 & 14,29 & 17,2 & 10,97 & 13746,29 & 4,86 & 30,12 \\
3 & Rh. mucronata & 10,3 & 2,13 & 5,2 & 3,32 & 3079,15 & 1.09 & 6,54 \\
4 & Rh.apiculata & 6,9 & 1,43 & 6,9 & 4,40 & 2257,58 & 0,80 & 6,63 \\
5 & Rh.stylosa & 22,4 & 4,64 & 8,6 & 5,48 & 5295,82 & 1,87 & 11,99 \\
6 & Avicenia marina & 17,2 & 3,56 & 10,3 & 6,57 & 4665,06 & 1,65 & 11,78 \\
7 & Avicenia alba & 8,6 & 1,78 & 5,2 & 3,32 & 3605,04 & 1,27 & 6,37 \\
8 & X. granatum & 1,7 & 0,36 & 1,7 & 1,08 & 6643,97 & 2,35 & 3,79 \\
9 & Br. gymnorrhiza & 8,6 & 1,78 & 1,7 & 1,08 & 4369,92 & 1,54 & 4,40 \\
10 & Ceriops tagal & 13,8 & 2,86 & 3,4 & 2,17 & 2351,61 & 0,83 & 5,86 \\
\hline \hline
\end{tabular}

Keterangan : KJ = Kerapatan Jenis, KR = Kerapatan Relatif, FJ = Frekuensi Jenis, FR = Frekuensi Relatif, DJ = Dominasi Jenis, DR = Dominansi Relatif, NP = Nilai Penting

Tabel 6. Hasil Perhitungan Nilai Penting Untuk Kategori Sapihan

\begin{tabular}{clrrrrrrr}
\hline \hline No & Spesies Mangrove & KJ & KR & \multicolumn{1}{c}{ FJ } & \multicolumn{1}{c}{ FR } & \multicolumn{1}{c}{ DJ } & \multicolumn{1}{c}{ DR } & \multicolumn{1}{c}{ NP } \\
\hline \hline 1 & Sonneratia alba & 765,5 & 51,86 & 172,4 & 44,71 & 23338,46 & 53,29 & 149,86 \\
2 & A. corniculatum & 531,2 & 35,99 & 96,4 & 25,00 & 15565,01 & 35,54 & 96,53 \\
3 & Rh. Mucronata & 27,6 & 1,87 & 6,8 & 1,76 & 92,80 & 0,20 & 3,83 \\
4 & Rh. Apiculata & 27,6 & 1,87 & 27,6 & 7,16 & 561,17 & 1,28 & 10,31 \\
5 & Rh.stylosa & 55,2 & 3,74 & 41,2 & 10,68 & 1925,10 & 4,39 & 18,81 \\
6 & Avicenia marina & 6,8 & 0,46 & 13,6 & 3,54 & 177,90 & 0,42 & 4,42 \\
7 & Avicenia alba & 20,8 & 1,41 & 6,8 & 1,76 & 685,81 & 1,57 & 4,74 \\
8 & X. granatum & 0 & 0 & 0 & 0 & 0 & 0 & 0 \\
9 & Br.gymnorrhiza & 6,8 & 0,46 & 20,8 & 5,39 & 0 & 0 & 5,85 \\
10 & Ceriops tagal & 34,4 & 2,34 & 0 & 0 & 1448,50 & 3,31 & 5,65 \\
\hline \hline & Jumlah & $1.475,9$ & 100 & 385,6 & 100 & 43794,75 & 100 & 300 \\
\hline \hline
\end{tabular}

Keterangan : KJ = Kerapatan Jenis, KR = Kerapatan Relatif, FJ = Frekuensi Jenis, FR = Frekuensi Relatif, DJ = Dominasi Jenis, DR = Dominansi Relatif, NP = Nilai Penting

Pada tingkat pohon dan sapihan spesies Sonneratia alba mendominasi lokasi penelitian di muara sungai Siganoi. Jenis ini di lapangan tampak sebagai populasi murni dan seragam dengan ukuran pohon makin mendekati garis pantai. Nilai penting jenis ini pada tingkat pohon dan sapihan masing-masing sebesar $212,52 \%$ dan $149,86 \%$.

Spesies A. corniculatum pada tingkat pohon $(30,12 \%)$ dan sapihan $(96,53 \%)$ masih mendominasi setelah Sonneratia alba. Spesies lain yang memiliki nilai penting di atas $10 \%$ pada tingkat pertumbuhan pohon adalah Rh.stylosa (11,99 \%) dan Avicenia marina $(11,78 \%)$, sedangkan pada tingkat sapihan
Rh.stylosa (18,81\%) dan Rh.apiculata (10,31 $\%)$.

Spesies-spesies ini sangatlah berpengaruh dan berperan aktif dalam suatu komunitas (Bengen, 2000). Pengaruh dan peranan dari spesies-spesies ini dalam komunitas pesisir muara sungai Siganoi antara lain sebagai individu yang jumlahnya sangat banyak terdapat pada setiap kuadran dan sebagai spesies pioner yang tumbuhnya di bagian depan dengan bentuk pohon yang cukup besar sangat bermanfaat sebagai penahan amukan gelombang laut yang sangat kuat, sekaligus berfungsi juga sebagai pelindung bagi spesiesspesies yang lain yang umumnya tidak tahan terhadap amukan gelombang laut. 


\section{Kesimpulan}

Komunitas vegetasi mangrove di pesisir muara sungai Siganoi di distrik Inanwatan, Kabupaten Sorong Selatan ditemukan tersusun dari tujuh famili yang meliputi 12 spesies. Kerapatan jenis vegetasi mangrove tertinggi untuk kategori pohon dan sapihan dimiliki oleh spesies $S$. alba, sedangkan untuk kategori anakan dimiliki oleh spesies $A$. corniculatum.

Spesies mangrove yang memiliki daerah penyebaran paling luas untuk tingkat pertumbuhan pohon dan sapihan masih didominasi spesies $S$. alba dan $A$. corniculatum, sedangkan untuk kategori anakan dimiliki oleh spesies A. corniculatum. Vegetasi mangove muara sungai Siganoi pada tingkat pertumbuhan pohon dan sapihan didominasi oleh spesies $S$. alba dan $A$. corniculatum.

Nilai penting spesies penyusun mangrove muara sungai Siganoi (di atas $10 \%$ ) pada tingkat pertumbuhan pohon dan sapihan berturut-turut adalah $S$. alba, A. corniculatum, Rh.stylosa, Avicenia marina dan Rh.apiculata.

\section{Saran}

Perlu adanya penelitian lanjutan tentang faktor-faktor kimia dan fisik lingkungan seperti kondisi subtrat, salinitas, serta tinggi genangan air saat pasang dan surut yang erat kaitannya dengan pertumbuhan komunitas mangrove di muara sungai Siganoi.

\section{Daftar Pustaka}

Bengen, D. 2002. Pengenalan dan Pengeloaan Ekosistim Mangrove. PKSPL-IPB Bogor

Cintron, G. dan Novelly. 1984. Methods for Studying Mangrove Structure in The Mangrove Ecosystem Research Methods. The United Nation Educational Scientific and Cultural Organization.

Darsidi, A.A. 1986. Perkembangan Pemanfaatan Hutan Mangrove di Indonesia. Pros. Seminar III Ekosistem Mangrove. LIPI Jakarta.

Dahuri, Rais, R.J., Ginting, S.P. dan Sitepu, M.J. 1996. Pengelolaan Sumber Daya Wilayah Pesisir dan Lautan Secara Terpadu. Pradnya Paramita. Jakarta.

Doubenmire, R.F. 1974. Plant and Environment. John Willey and Sons. New York

Mueller-Dombois, D. and Ellenberg, H. 1974. Aims and Methods of Vegetation Ecology. John Willey and Sons. New York.

Onrizal. 1997. Pengenalan Kunci Determinansi Jenis Pada Mangrove di Teluk Bintuni Irian Jaya. Skripsi Fakultas Kehutanan IPB. Bogor.

Setyawan, A.D., Indrowuryatno, Wiryanto, Winarno, K. dan Susilowati, A. 2005. Tumbuhan Mangrove di Pesisir Jawa Tengah: 1. Keanekaragaman Jenis. Biodiversitas. Journal of Biological Diversity. 6 (2) April 2005. Jurusan Biologi FMIPA Universitas Sebelas Maret Surakarta. 